\title{
Stock Returns' Behavior in Different Power Regimes: An Exploratory Data Analysis of Agri-Tractor Manufacturers
}

\author{
Hassan Mujtaba Nawaz Saleem ${ }^{1}$, Nurwati A. Ahmad-Zaluki² \\ ${ }^{1}$ OYAGSB, Universiti Utara Malaysia, 06010 UUM Sintok, Kedah Darul Aman, Malaysia \\ Department of Management Sciences, The Islamia University of Bahawalpur, BJ Campus, Bahawalpur-63100 Pakistan \\ ${ }^{1}$ E-mail: Hassan.Saleem@iub.edu.pk (Corresponding author) \\ 20YAGSB, Universiti Utara Malaysia, 06010 UUM Sintok, Kedah Darul Aman, Malaysia, ${ }^{2}$ E-mail: nurwati@uum.edu.my
}

\begin{abstract}
The agriculture sector of Pakistan is regarded as the backbone of the economy as it contributes towards the country's GDP 21.40 percent, where, around 65 percent of the country's population is involved either direct or indirect. However, little has been researched, mainly focusing on the stock returns behavior during different political parties and caretaker government (CTG) power regimes. The study empirically investigated the issue by applying exploratory data analysis techniques to daily stock returns of Agri-tractor manufacturer companies (i.e. possess 99\% market share) listed at the Pakistan Stock Exchange. The study covers seven different power regimes that include four mainstream political parties and three CTGs, starting from 23rd November 2002 to 31st May 2019. Comparing stocks return performance of Pakistan Tehreek-e-Insaaf (PTI) power regime seems to be biased as it is a relatively new political party who the first time is leading the country in its lifetime compared to its counterparts. Moreover, it still has left with its remaining four years to be in power. However, the stock return performances during the PTI power regime show more resemblance to the CTGs than the mainstream political parties. Overall, extreme fluctuation has been observed in Agritractor manufacturer companies stocks return during all major political parties' power regimes except PTI. If ranked, the PML-Q could be placed on the high returns' volatility side and PML-N on the low-volatility, whereas PPP in the mid. However, the variations are minor among the regimes in the context of stock return fluctuations. The study can help investor in their portfolio construction process and may have better returns if they pay attention to these political dynamics.
\end{abstract}

Key words Stock Returns' Behavior, Political Power Regime, Exploratory Data Analysis, Government Political Orientation, Agri-Tractor Manufacturers

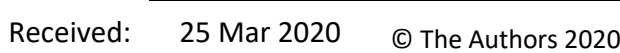

Revised: 20 Apr 2020 Published by Human Resource Management Academic Research Society (www.hrmars.com)

Accepted: 05 May 2020 This article is published under the Creative Commons Attribution (CC BY 4.0) license. Anyone may Published Online: 10 May 2020 reproduce, distribute, translate and create derivative works of this article (for both commercial and non-commercial purposes), subject to full attribution to the original publication and authors. The full terms of this license may be seen at: http://creativecommons.org/licences/by/4.0/legalcode

\section{Introduction}

The stock market is the place where 'shares' or 'stocks' of the corporations are traded among investors and traders. Prices of these stocks are determined by the demand-supply mechanism all over the world. Although controversy exists, however, the traditional beliefs about the stock market are perceived as the predictor of an economy. The common perception among many believers prevails that stock prices significant decreases reflect future recession, whereas future economic growth can be inferred on huge stock prices increase (Comincioli, 1996). Over time, the behavior of the stock markets has been observed very complex. For that reason, it received special attention from practitioners and academia everywhere. The dynamics of the stock market has been recognized as the issue of central importance, particularly in 
hedging strategies, optimal portfolio allocations, and regulatory policy actions. For this, several models have been developed to capture asset prices dynamic patterns of the series. Often, these models are grounded on the error terms normality and stationarity or innovations returns, whereas for financial and macroeconomic time series, non-Gaussian distributions have got popularity (Bhar et al., 2008; Hamilton, 1989; Loretan \& Phillips, 1994).

Similarly, ample literature from the developed world produced pieces of evidence about the political orientation of the incumbent government's influences on the stock returns (Croce et al., 2012; Darrat, 1988, 1990; Thorbecke, 1997). Where the collective stock price movements determine the behavior of the stock market, Hibbs (1977) believed that the political parties based on their own electorate needs' priority might use policy instruments once they are in power. Hence, like in the developed world, the stocks of companies operating in developing countries such as India, Bangladesh, and Pakistan cannot be the exception. Instead, strong political influence can be anticipated due to the relatively weak institutions as compared to the developed nations such as United States (US), United Kingdom (UK), Canada, and Germany, etc. Therefore, the political orientations of the parties who come into power must influence the company stock returns in Pakistan as well. Pakistan, being a multi-party democratic country, has many political parties that may be classified far-left, center-left, center-right, and far-right parties. In the past, many times, it had coalition governments in power. It has a bicameral parliamentary system consisting of the National Assembly and Senate. Since the year 2002, the seventh government is currently is in the office where three major political parties have completed their five-year terms, and three care-taker governments held the office for interim periods. Table 1 gives details of the Pakistani political parties who have been holding offices their respective power regimes.

Table 1. Political Party and their Power Regimes in Pakistan

\begin{tabular}{cl|c|c}
\hline Sr. No. & \multicolumn{1}{c|}{ Name of Political Party in Power } & Start-Date & End-Date \\
\hline 1 & Pakistan Muslim League (PML-Q) & 23 November 2002 & 15 November 2007 \\
2 & Care-Taker Government-I (CGT-I) & 16 November 2007 & 24 March 2008 \\
3 & Pakistan People's Party (PPP) & 25 March 2008 & 24 March 2013 \\
4 & Care-Taker Government-II (CGT-II) & 25 March 2013 & 04 June 2013 \\
5 & Pakistan Muslim League (PML-N) & 05 June 2013 & 31 May 2018 \\
6 & Care-Taker Government-III (CGT-III) & 01 June 2018 & 17 August 2018 \\
7 & Pakistan Tehreek-e-Insaaf (PTI) & 18 August 2018 & To-date \\
\hline
\end{tabular}

Notes: The PTI is expected to remain in power till August 2023, therefore, comparing its partial regime does not seems logical. The power regime is discussed only for the initial regime perspective only.

Source: Government of Pakistan

The agriculture sector of Pakistan is regarded as the backbone of the economy as it contributes towards the country's GDP 21.40 percent, which produces raw material for the essential industries such as sugar and textile. Iqbal et al. (2015) noted that either direct or indirect, around 65 percent of the country's population is involved in agriculture. The tractors are the most critical machinery that is being utilized as central to the entire agriculture production process, starting from land preparation to the product delivery to the market. However, little has been researched with particular focus to such an important sector. The Pakistan Stock Exchange has got two companies listed under the automobile assembler business sector who manufacture Agri-tractors. These two companies constitute for 99 percent market share, where AlGhazi Tractors Ltd.(AGTL) company's brand "Fiat" and Millat Tractors Ltd. (MTL) brand "Massey Ferguson" possess 50.90 percent and 40.10 percent of the total market share, respectively (Qadir, 2016). Hence, with these backdrops, this study contributes to the literature in different dimensions.

In this article, we examine whether the stock returns dynamics in the Pakistan Stock Exchange (PSX) govern the behavior of the market over different political parties' regime. Our motivation stems from the fact that little has been done on this market. The financial assets issued by the market are integrated parts of dedicated diversification strategies of investors. Our analysis thus allows for a comparison of market behavior during different political parties' government regimes since the year $23^{\text {rd }}$ November 2002 to $31^{\text {st }}$ May 2019. It accounts for the potential impacts of seven different government regimes. Furthermore, we use EDA to understand the stock market dynamics. The results of our investigation are particularly useful 
for portfolio managers and market authorities as far as they are respectively concerned by accurate portfolio allocation decisions and the stock market efficiency improvements. Finally, we will explore the change in PSX behavior with the turn of the government's regime, in the sense that the variation in governments influences the market outcomes.

\section{Literature review}

The shareholders may have to face important consequences due to the macroeconomic policy mix choices adopted by the governments (Wisniewski, 2016). In IS-LM extended framework, a theoretical link has been established by Blanchard (1981) between the stock prices and fiscal monetary expansions. Shah (1984) model highlights that the capital price in the stock market during the short-run periods can experience jumps to respond to the "money-financed fiscal expansion" implementations. Whereas, Croce et al. (2012) are of the view that the cost of equity is raised because of the volatility in the government expenditures and taxation increases. If we look into the practical side, the Canadian economy confirmed that the future prices of the stocks tend to be driven through the government budget deficits' changes (Darrat, 1988, 1990). Whereas, in the US policy choices, the returns of the ex-post stock increases due to the expansionary monetary policy adoption (Thorbecke, 1997). This implies that the decisions made by the leadership of a particular country are of great significance. It is, therefore, likely to reflect the incumbents' ideology at least to an extent. The political parties, based on their own electorate needs' priority, may use policy instruments once they are in power. The Hibbs (1977) Partisan Theory postulates that the occupational status and lower-income groups tend to support the parties that are at the left of the political spectrum. Rather than physical capital, the human capital holds in this electorate type; therefore, it displays high unemployment sensitivity. On the other side, the right-wing parties are usually supported by the members of the society that are more affluent, holding secure jobs, very much concerned about the inflation. Since the macroeconomic outcomes of the Hibbs (1977) model move along the Phillips curve, therefore, pursuing the low unemployment and inflation goals have no compatibility. Instead of this, depending upon their ideological inclination, these two goals' importance has to be weighed by the political parties. Consequently, under the Socialist-Labor Parties, the outcomes remained low unemployment/high inflation, whereas the Conservative Parties constellate on the other side of the Phillips curve. Hence, the idea of the rational expectation got incorporated in the subsequently developed second generation's models, which are referred to as 'Rational Partisan Theory' in the literature. The macroeconomic outcomes can be affected, in these models also, by the parties' ideological differences that most likely happen during their first half term in power (Alesina, 1987; Alesina \& Sachs, 1988; Chappell \& Keech, 1986).

Hensel \& Ziemba (1995) addressed the question of whether stocks' valuation reflects partisan cycles. They discovered from the years 1929-1992 data that per annum earnings of the small-capitalization stocks remained 20.54 percent and 1.94 percent under Democratic and Republican administrations, respectively. The huge earning gap is statistically as well as economically significant to allow profitable trading strategies implementation. Johnson, Chittenden, and Jensen (1999) also confirmed the findings and reported an over 20 percent annual partisan return difference for small stocks between the administrations. Similarly, Santa-Clara \& Valkanov (2003) reported the return gap estimates between Republican and Democratic presidencies for the value-weighted index and equally-weighted index as 9 percent and 16 percent, respectively. They further emphasized that after taking into account the business cycle variables, this anomaly persists. Lastly, Belo et al. (2013) concluded that not only small-cap stocks display the partisan return cycle but the companies with high government spending exposure industries also produce similar evidences.

Interestingly, Sy \& Al Zaman (2011) concluded that the significant difference exhibited in size and market risk premiums across Democratic and Republican presidencies could explain the puzzle. In other words, during Democrats, power regime investors require a higher rate of return, which has been reflected in the market prices' movements. If their interpretation is considered correct, then it should follow two results. First, even if the investors are assumed to be rational, the returns' partisan cycle should be observed clearly. Second, to the elections results' announcement, there should get a reaction in the prices. Similar to the Democratic presidents' case, there will be massive future cash flows discount if there is an increase in the required rate of return, and around the elections results announcements, the prices of the 
stocks should drop. Based on the risk-compensation stories and presidential puzzle, it can be inferred that the initial drop in the stock prices will follow high returns in the next four years. That is, the stock prices will immediately increase with the Republican win, and disappointing returns will be followed during their office term. In other words, there should be a transient effect of the announcement in the opposite direction to the partisan cycle's predicted path. Hence, the Sy \& Al Zaman (2011) implied theoretical explanation empirically confirmed. In short event windows, the stock market reacts negatively to the Democrats' victory and positive when the Republicans had the success in the presidential race (Niederhoffer et al., 1970; Riley \& Luksetich, 1980). Similarly, Snowberg et al. (2007) estimated 2-3 percent stock return from the election-eve close post-election close when Republicans win the elections. Thus, it can be believed that there is no market inefficiency despite the returns' predictable patterns, and there is just compensation for the investors for bearing risks. However, the US research results cannot be easily generalized to the global context. For instance, Cahan et al. (2005) documented that the real stock returns in New Zealand under the Labour government (i.e. left-wing) were significantly lower compared with the National governments (i.e. right-wing). Similar tendencies were also observed in Australia (Anderson et al., 2008). The short period evidence around British elections suggests that the Conservative Party rightist had got a preference in the market (Herron, 2000). However, across Labour and Conservative governments, there was no significant difference in the real or nominal returns when looked at the entire term in office (Hudson et al., 1998).

Similarly, the pieces of evidence from the German federal election of the year 2002 shows a positive relationship between small stocks' returns and the probability of right-wing coalition victory (Füss \& Bechtel, 2008). Moreover, according to Döpke \& Pierdzioch (2006), compared with the government of the left-wing, the returns of the German stock tend marginally higher in the right-wing regime. Another comprehensive investigation based on the 24 OECD countries' sample tried to understand the executive's political orientation influence on the fluctuation of the local stock market by focusing on the parliamentary or presidential systems of the elections (Bialkowski et al., 2007). Their analysis of 173 presidencies and the governments show no statistical differences in returns due to partisan even if election periods or whole incumbencies considered. In sum, stock market investors' political preferences depend on the environment of a specific country. Hence, the international political landscape complexities seem very unlikely to be captured by simple generalizations. The paper contributes towards the existing literature by investigating the stocks prices time series listed at the PSX classified under automobile assemblers' business sector through EDA to understand the stock market behavior. As stated, such researches are available for developed countries such as the US, Canada, Germany, etc. however, we do not find any such study focusing on PSX listed stocks. Hence, the information uncovered in this study will benefit the investors and traders (i.e. national and international) in optimally apportioning their limited capital. It will also be helpful to the regulator and policymakers in their market regulations preparations and policy formulation and implementation decisions to protect the investors, especially when the market switches downturns.

\section{Methodology of research}

The stock price closing data of the PSX listed Agri-Tractors manufacturer companies are collected from the PSX database. However, to cross-check and fill-in the missing data, the data also collected from DataStream and Bloomberg sources. The study period starts on $23^{\text {rd }}$ November 2002 and ends on $31^{\text {st }}$ December 2019. We left with the 4,155 observations of each stock (i.e. AGTL and MTL) after the data cleaning process. Returns for each stock and the whole cluster are computed with the loss of ' 1 ' observation. Therefore we left with " $4,155^{*} 3=12,465$ " observations, finally.

For data analysis, we use Cox (2017) exploratory data analysis techniques to have inferences based on the results obtained. Jebb et al. (2017). Celestini et al. (2017) suggested that with the application of EDA, the data can be explored, and it plays a critical role during the data analysis process. Through this approach, the mistakes can be identified, assumptions can be checked, and the tendencies and relationships can be determined. Therefore, the EDA approach is considered to be the best approach especially when a broad audience is targeted who have understandability differences regarding technical statistics. 


\section{Empirical results and discussions}

\subsection{Summary Statistics}

Over the last eighteen years, Pakistan had seven governments with different tenures in their offices. Since the year 2002, the seventh government is in power nowadays.

Each of the four governments has different formal political orientations such as far-left, center-left, center-right, and right), etc. However, the CTGs come in power for an interim to conduct elections and pass on the power to the next winning parties as a result of the democratic voting process. It is usually considered as governments with no clear political orientation. Therefore, besides the political parties-led government, three CTGs held power in the interim during the sample period of the study. Table 2 gives a brief statistical description of the sample consisting of PSX listed Agri-Tractor producers, which started from $23^{\text {rd }}$ November 2002 to $31^{\text {st }}$ December 2019.

Table 2. Summary Descriptive Statistics of Agri-Tractor Producers Listed at PSX

\begin{tabular}{l|cccc|ccc}
\hline \multirow{2}{*}{ Classifications } & \multicolumn{3}{|c|}{ Formal Political Party in Power Regimes } & \multicolumn{3}{c}{ Interim Government Regimes } \\
\cline { 2 - 7 } & PML-Q & PPP & PML-N & PTI & CTG-I & CTG-II & CTG-III \\
\hline Mean & 0.00079 & 0.00022 & 0.00077 & -0.00227 & 0.00106 & 0.00030 & -0.00065 \\
Standard Error & 0.00052 & 0.00050 & 0.00044 & 0.00104 & 0.00152 & 0.00091 & 0.00169 \\
Std Deviation & 0.01817 & 0.01757 & 0.01555 & 0.01485 & 0.01405 & 0.00647 & 0.01263 \\
Sample Var. & 0.00033 & 0.00031 & 0.00024 & 0.00022 & 0.00020 & 0.00004 & 0.00016 \\
Kurtosis & 43.67053 & 25.17629 & 6.89134 & 2.04014 & 2.65542 & 1.85713 & 2.37940 \\
Skewness & -3.42405 & -2.41272 & -0.45781 & 0.21259 & 0.22124 & 0.92816 & -0.27130 \\
Range & 0.31673 & 0.25322 & 0.19450 & 0.10334 & 0.09871 & 0.03371 & 0.07776 \\
Minimum & -0.24448 & -0.20444 & -0.13890 & -0.04802 & -0.04993 & -0.01220 & -0.03937 \\
Maximum & 0.07225 & 0.04878 & 0.05560 & 0.05532 & 0.04878 & 0.02151 & 0.03839 \\
Sum & 0.97200 & 0.26994 & 0.95534 & -0.46177 & 0.08983 & 0.01547 & -0.03655 \\
Count & 1228 & 1241 & 1240 & 203 & 85 & 51 & 56 \\
Largest(1) & 0.07225 & 0.04878 & 0.05560 & 0.05532 & 0.04878 & 0.02151 & 0.03839 \\
Smallest(1) & -0.24448 & -0.20444 & -0.13890 & -0.04802 & -0.04993 & -0.01220 & -0.03937 \\
Con. Lev(99.0\%) & 0.00134 & 0.00129 & 0.00114 & 0.00271 & 0.00402 & 0.00243 & 0.00450 \\
\hline
\end{tabular}

Notes: PML-Q: “Pakistan Muslim League (Q-Group)", PPP: “Pakistan People's Party”, PML-N: Pakistan Muslim League (N-Group) are the major political of Pakistan, whereas, CTG-I, CTG-II, and CGT-III represents the caretaker governments appointed as per the constitution of Pakistan to conduct free and fair elections in the country to pass-on the power to a party whom citizens of Pakistan vote for during the democratic electoral process.

\section{Source: Author's computation}

The descriptive statistics uncover interesting information about the PSX listed Agri-tractor manufacturer companies' stock behaviors in different political regimes. The mean returns during PML-Q were high and also showed the highest standard deviation as compared to the other parties' regimes. This means that the stocks remained highly volatile during this period. In contrast, the stocks showed less volatility in the PTI government period. Moreover, it cannot disclose the information concerning the whole regime as the government has just completed around a year in power. On the other side, in this context, the CTG-I regime shows better compared with the other regimes where CTGs remained in power.

Surprisingly, the PML-Q regime who had the highest mean return also shows high kurtosis (i.e. 43.67), which means that it had heavy tails or the outliers which confirm the abnormal return indications. Whereas, the PTI regime, which is still on-going, has low mean returns show the lowest kurtosis among the other parties' regimes. That indicates that no abnormal returns signals are found so for. The kurtosis statistics of the stock returns in all CTG governments' periods display PTI government the same behavior.

Similarly, the skewness in statistics and probability theory measures the asymmetries of the probability distributions of a random variable about its mean real-valued. An interesting trend has been observed in the Agri-tractors companies stocks returns skewness statistics that the skewness, which was highly negatively skewed in PML-Q party government duration, started slipping to the other end. That is evidenced by the skewness statistics in "PML-Q," "PPP," "PML-N," and "PTI" power regimes are "-3.42", "2.41 ", "- 0.46 ", and " 0.21 ", respectively. More interestingly, The CTG-I followed the PML-Q regime. The stocks return' skewness turned from negative to positive. The PPP regime followed the CTG-I regime, 
where stocks return' skewness turned from positive to negative. Then, CTG-II followed the PPP regime, and they turned from negative to positive. Then PML-N followed the CTG-II regime, and they turned from positive to negative. Then, CTG-III followed the PML-N regime, and the stocks return skewness remained negatively skewed.

\subsection{PSX Listed Agri-Tractor Manufacturer Companies Stocks Performances in Each Political Party and CTG Regimes}

As discussed above, there are two companies (i.e. AGTL and MTL) that are producing Agri-tractors in Pakistan that are listed at PSX as well. During the period of the last eighteen years, these stocks returns have displayed interesting information in each political party and CTGs regimes' power durations. Fig.-1 displays the status of the PSX listed Agri-tractor manufacturer companies stocks daily returns during different political parties and CTGs in power regimes covering the entire study duration (i.e. $23^{\text {rd }}$ November 2002 to $31^{\text {st }}$ December 2019).

Panel A: Stocks daily returns status during different political parties power regimes

PML-Q in Power Regime

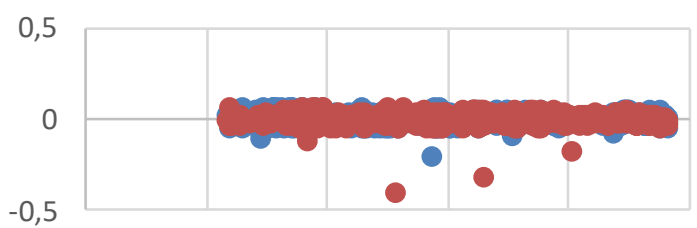

PML-N in Power Regime

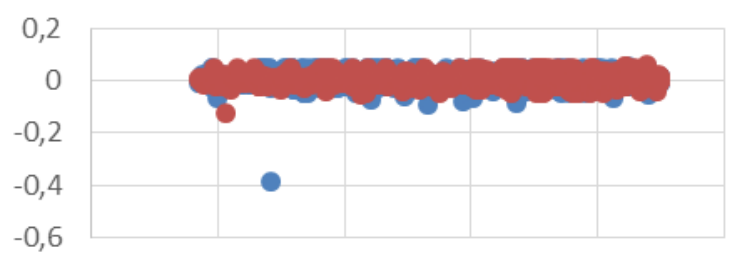

PPP in Power Regime

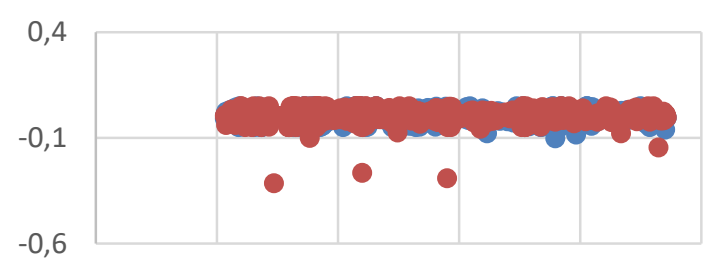

PTI in Power Regime

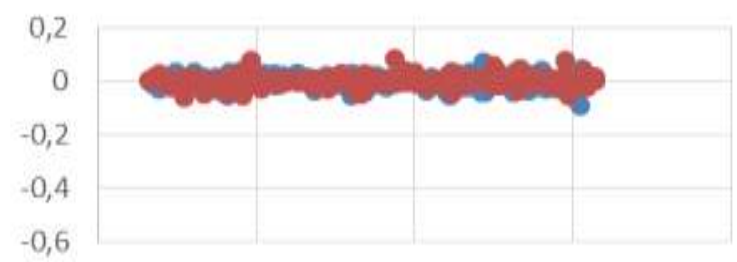

Panel B: Stocks daily returns status during different CGTs power regimes, and study period

CTG-I in Power Regime

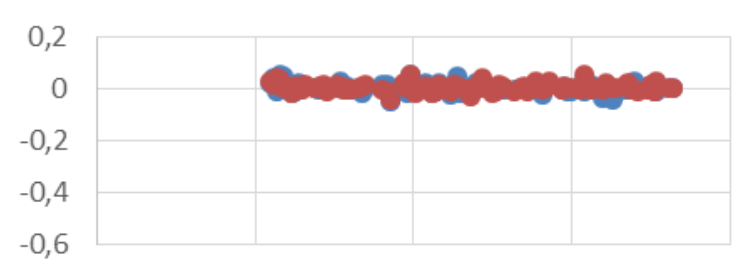

CTG-III in Power Regime

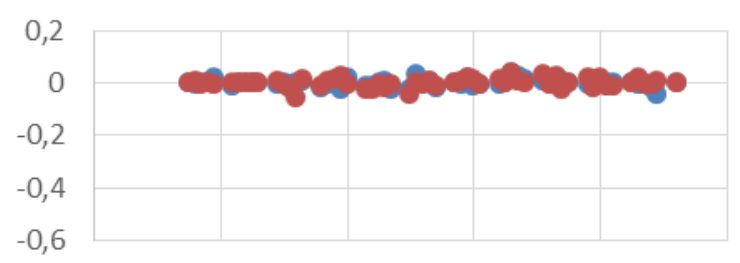

CTG-II in Power Regime

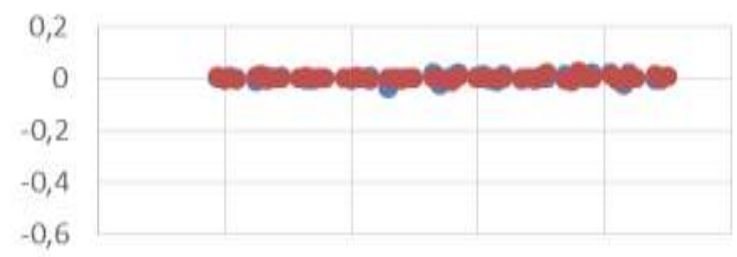

Total Sample 2002-2019

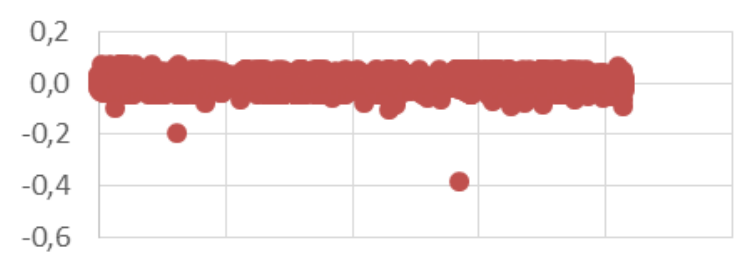

MTL

Notes: PML-Q: “Pakistan Muslim League (Q-Group)”, PPP: “Pakistan People's Party”, PML-N: Pakistan Muslim League (N-Group) are the major political of Pakistan, whereas, CTG-I, CTG-II, and CGT-III represents the different care-taker governments with political orientation, "AGTL" represents "Al-Ghazi Tractors Ltd., and "MTL" represents "Millat Tractors Ltd." 
Figure 1. Status of the PSX Listed Agri-Tractor Manufacturer Companies Stock daily Returns During Different Political Parties and Care-Taker Governments in Power Regimes

Source: Author's computed and displayed

From the above, we can observe the variations that each Agri-tractor manufacturer stocks returns displays in each political and CTGs power regime. Before comparing the performances of the stock in different power regimes, it seems logical to analyze each company stock returns behavior in each power regime isolated. Hence, stocks behaviors in different regimes are discussed below.

\subsubsection{Stocks Behavior During PML-Q Political Party Power Regime}

The PML-Q emerged in Pakistan after the year 1999 military takeover of the country having more members from its old party (i.e. Pakistan Muslim League (PML)). As per the political orientation alignments, the party can be placed on the center-right. The stocks show high volatility during this period with relatively more sudden jumps towards the downward direction where the shareholder had to experiences huge losses. However, among the stocks, AGTL had enjoyed more positive returns as compared to the MTL. Similarly comparing to the AGTL, MTL investors faced more downside jump incidence and suffered huge losses as a consequence, whereas, the AGTL investors remained better during this period. Therefore, from these observations, it can be inferred that AGTL had better circumstances during this period, or the regime remained more favorable to the AGTL.

\subsubsection{Stocks Behavior During CTG-I Power Regime}

As the CTG-I government has no political orientations, therefore it can only be fitted in the center of the political party's alignment grid. The same displayed in stocks returns graph plot that shows far less volatility has been observed in both the stocks during this period. During this regime, both stock returns remain more on the positive side. Therefore, the shareholders' returns remained stable, but no abnormal returns also. If compared among the stocks, AGTL had enjoyed more positive returns slightly as compared to the MTL, however not much significant. Therefore, it is it can be inferred from these observations that the period remained calm for the Agri-tractor manufacturers company stocks investors.

\subsubsection{Stocks Behavior During PPP Political Party Power Regime}

The PPP is the only right-wing party that remained in power during the study period. Therefore, as per the political orientation alignments, the party can be placed in the extreme-right of the grid. During this regime, stocks also showed high volatility with relatively more sudden jumps towards the downward direction. Among the stocks, compared to the MTL, AGTL had enjoyed more positive returns. The MTL investors faced more downside jump incidence and suffered huge losses as a consequence compared to the AGTL company stocks investors. That means the AGTL investors remained better during the PPP part power regime. Therefore, based on these observations, it can be inferred that AGTL company stocks investors had better circumstances during this period, or for AGTL, the regime remained more favorable.

\subsubsection{Stocks Behavior During CTG-II Power Regime}

As discussed above (i.e. in section 4.2.2) that the CTGs are selected based on no political orientations, therefore CTG-II can only also be fitted in the center of the political party's alignment grid. Similar to the CTG-I regime, both the stocks displayed very little volatility during this period. During this regime, both stock returns remain more on the positive side, resultantly, the shareholders' returns remained stable but no abnormal returns. However, if closely observed, the spread shrunk more that means no significant profits or losses to the shareholders.

\subsubsection{Stocks Behavior During PML-N Political Party Power Regime}

The PML-N has its historical background from its old party (i.e. Pakistan Muslim League (PML)). It emerged after the year 1999 military take-over having PML left-over members also included members from PPP as well. Like other political parties, it also introduced very new faces from the Pakistani business elite. 
In the context of alignment of political party orientation, the PML-N can be placed in the far-right of the grid alignment. In this period, the stocks showed high volatility was relatively more sudden downward jumps. This means that the shareholders have had experienced significant losses. During the PML-N regime, the AGTL stocks had better prospects and enjoyed more positive returns as compared to the MTL. The MTL investors faced more downside jump comparing to the AGTL incidences and, consequently, suffered significant losses. The AGTL investors during the PNL-N power regime remained better. Hence, it can be inferred from these observations that among the Agri-tractor manufacturers, the regime remained more favorable to the AGTL compared to the counterpart.

\subsubsection{Stocks Behavior During CTG-III Power Regime}

The CTGs are selected based on no political orientations, as discussed above (i.e. in section 4.2.2 and 4.2.4). Therefore CTG-III has been placed in the center of the political party's alignment grid too. Both the stocks displayed very little volatility during this period, like other CTG governments, which remained in power during the entire study period. During this regime, both stocks' return remains more on the positive side. Resultantly, the shareholders' returns remained stable but no abnormal returns. However, if closely observed, the spread shrunk but lesser than the CTG-II and shows no significant profits or losses to the shareholders. The overall stocks return behavior remained more or less alike CTG-II regime. Although there no clear signals observed, however, AGTL seems slightly more positive returns as compared to the MTL. Therefore, based on these observations, the period remained calm for the Agri-tractor manufacturers' company stocks investors can be inferred.

\subsubsection{Stocks Behavior During PTI Political Party Power Regime}

The PTI emerged in Pakistan during the year 1997. It is a relatively new party if compared to its counterparts who have been leading the country for decades. However, as per the political orientation alignments, the party can be placed on the center-right. The party has just completed its $1^{\text {st }}$ year in power, having the first-ever experience of leading the country, and still expected has to remain in power till the year 2023. In this period, the stocks showed far less volatility, with no sign of abnormal shifts in the returns. Unlike other major political parties, no abnormal returns pieces of evidence observed during PTI's period. During this regime, both stocks' return remains more on the positive side. Resultantly, the shareholders' returns remained stable. However, if closely observed, the spread shrunk but lesser than the CTGs. The overall stocks return behavior remained more or less alike CTGs regime with no clear favorable signals to any company. Therefore, the period can be said to be calm for the Agri-tractor manufacturers company stocks investors based on these observations.

\subsection{Stocks Behavior During Entire Study Period}

The comparison of PTI to the other mainstream political parties seems to be biased based on three strong points that, we believe, must need to be taken into consideration while comparing the performance of the returns of the stock during the political parties' power regimes. First, the PTI is a relatively new political party as compared to the other three major parties who had been ruling the country's inception. Second, the party came into power for the first time in its lifetime. Third, the party is still left with its four years to remain in power. However, the stock return performances show more resemblance to the CTGs than the mainstream political parties. Overall, the extreme fluctuation is observed in Agri-tractor manufacturer company stocks return during all three major political parties' power regime. The political processes restarted in Pakistan after the year 1999 military take-over in 2002. The new political parties emerged with having slight variations in their group identitiy. The party named PML had been divided in two parties PML-N, PML-Q having left-over members of the main PML and also included members from PPP as well. Later on, both became the mainstreamed parties and remained intact with their independent identities. Like other political parties, these parties also introduced very new faces from the Pakistani business elite. In the context of alignment of political party orientation, the PML-N can be placed in the farright of the grid alignment. If ranked, the PML-Q could be placed on the high returns' volatility side and PML-N on the low-volatility, whereas PPP in the mid. However, the variations are minor among the regimes in the context of stock return fluctuations. 


\section{Conclusions}

Although controversy exists, however, the traditional beliefs about the stock market are perceived as the predictor of an economy. The common perception among many believers prevails that stock prices significant decreases reflect future recession, whereas future economic growth can be inferred on huge stock prices increase (Comincioli, 1996). Similarly, ample literature from the developed world produced pieces of evidence about the political orientation of the incumbent government's influences on the stock returns (Croce et al., 2012; Darrat, 1988, 1990; Thorbecke, 1997), where the collective stock price movements determine the behavior of the stock market. Hibbs (1977) believed that the political parties based on their own electorate needs' priority might use policy instruments once they are in power. Pakistan, being a multi-party democratic country, has many political parties that may be classified far-left, center-left, center-right, and far-right parties. In the past, many times, it had coalition governments in power. It has bicameral parliamentary system consisting of National Assembly and Senate.

The agriculture sector of Pakistan is regarded as the backbone of the economy as it contributes towards the country's GDP 21.40 percent, which produces raw material for the important industries such as sugar and textile. The tractors are the most important machinery that is being utilized as central to the entire agriculture production process, starting from land preparation to the product delivery to the market. however, little has been researched with particular focus to such an important sector. Our motivation stems from the fact that little has been done on this market. The financial assets issued by the market are integrated parts of dedicated diversification strategies of investors. Our analysis thus allows for a comparison of market behavior during different political parties' government regimes since the year $23^{\text {rd }}$ November 2002 to $31^{\text {st }}$ May 2019. It accounts for the potential impacts of seven different government regimes. Furthermore, we use EDA to understand the stock market dynamics. The results of our investigation are particularly useful for portfolio managers and market authorities as far as they are respectively concerned by accurate portfolio allocation decisions and the stock market efficiency improvements. Finally, we will explore the change in PSX behavior with the change of the government's regime, in the sense that the variation in governments influences the market outcomes.

The comparison of PTI to the other mainstream political parties seems to be biased based on three strong points (1) it is a relatively new political party as compared to the other three major parties who had been ruling the country inception, (2) it came into power for the first time in its lifetime, and (3) the party is still left with its four years to remain in power. However, the stock return performances show more resemblance to the CTGs than the mainstream political parties. Overall, the extreme fluctuation is observed in Agri-tractor manufacturer company stocks return during all three major political parties' power regime. If ranked, the PML-Q could be placed on the high returns' volatility side and PML-N on the low-volatility, whereas PPP in the mid. However, the variations are minor among the regimes in the context of stock return fluctuations.

The paper contributes towards the existing literature by investigating the stocks prices time series listed at the PSX classified under automobile assemblers' business sector through EDA to understand the stock market behavior. As stated, such researches are available for developed countries such as the US, Canada, Germany, etc. however, we do not find any such study focusing on PSX listed stocks. The study can help investor in their portfolio construction process and may have better returns if they pay attention to these political dynamics. Hence, the information provides in this study, will benefit the investors and traders (i.e. national and international) in optimally apportioning their limited capital. It will also be helpful for the regulator in their market regulations preparations and policymakers in their policy formulation and implementation decisions to protect the investors, especially when the market switches downturns.

\section{References}

1. Alesina, A. (1987). Macroeconomic policy in a two-party system as a repeated game. The quarterly journal of economics, 102(3), 651-678.

2. Alesina, A., \& Sachs, J. (1988). Political parties and the business cycle in the US, 194881984. Journal of money, credit and banking, 20,63-82. 
3. Anderson, H. D., Malone, C. B., \& Marshall, B. R. (2008). Investment returns under right-and leftwing governments in Australasia. Pacific-Basin Finance Journal, 16(3), 252-267.

4. Belo, F., Gala, V. D., \& Li, J. (2013). Government spending, political cycles, and the cross section of stock returns. Journal of financial economics, 107(2), 305-324.

5. Bhar, R., Hammoudeh, S., \& Thompson, M. A. (2008). Component structure for nonstationary time series: Application to benchmark oil prices. International Review of Financial Analysis, 17(5), 971-983.

6. Bialkowski, J., Gottschalk, K., \& Wisniewski, T. P. (2007). Political orientation of government and stock market returns. Applied Financial Economics Letters, 3(4), 269-273.

7. Blanchard, O. J. (1981). Output, the stock market, and interest rates. The American Economic Review, 71(1), 132-143.

8. Cahan, J., Malone, C. B., Powell, J. G., \& Choti, U. W. (2005). Stock market political cycles in a small, two-party democracy. Applied Economics Letters, 12(12), 735-740.

9. Celestini, A., Me, G., \& Mignone, M. (2017). Tor marketplaces exploratory data analysis: The drugs case. Paper presented at the International Conference on Global Security, Safety, and Sustainability.

10.Chappell, H. W., \& Keech, W. R. (1986). Party differences in macroeconomic policies and outcomes. The American Economic Review, 76(2), 71-74.

11.Comincioli, B. (1996). The stock market as a leading indicator: An application of granger causality. University avenue undergraduate journal of economics, 1(1), 1.

12.Cox, V. (2017). Exploratory data analysis Translating Statistics to Make Decisions (pp. 47-74): Springer.

13.Croce, M. M., Kung, H., Nguyen, T. T., \& Schmid, L. (2012). Fiscal policies and asset prices. The Review of Financial Studies, 25(9), 2635-2672.

14.Darrat, A. F. (1988). On fiscal policy and the stock market. Journal of money, credit and banking, 20(3), 353-363.

15.Darrat, A. F. (1990). Stock returns, money, and fiscal deficits. Journal of Financial and Quantitative Analysis, 25(3), 387-398.

16.Döpke, J., \& Pierdzioch, C. (2006). Politics and the stock market: Evidence from Germany. European Journal of Political Economy, 22(4), 925-943.

17.Füss, R., \& Bechtel, M. M. (2008). Partisan politics and stock market performance: The effect of expected government partisanship on stock returns in the 2002 German federal election. Public Choice, 135(3-4), 131-150.

18. Hamilton, J. D. (1989). A new approach to the economic analysis of nonstationary time series and the business cycle. Econometrica: Journal of the Econometric Society, 357-384.

19.Hensel, C. R., \& Ziemba, W. T. (1995). United States investment returns during Democratic and Republican administrations, 1928-1993. Financial Analysts Journal, 51(2), 61-69.

20.Herron, M. C. (2000). Estimating the economic impact of political party competition in the 1992 British election. American Journal of Political Science, 326-337.

21.Hibbs, D. A. (1977). Political parties and macroeconomic policy. American political science review, 71(4), 1467-1487.

22.Hudson, R., Keasey, K., \& Dempsey, M. (1998). Share prices under Tory and Labour governments in the UK since 1945. Applied Financial Economics, 8(4), 389-400.

23.lqbal, M. A., Iqbal, A., Afzal, S., Akbar, N., Abbas, R. N., \& Khan, H. Z. (2015). In Pakistan, agricultural mechanization status and future prospects. American-Eurasian Journal of Agricultural \& Environmental Sciences, 15(1), 122-128.

24.Jebb, A. T., Parrigon, S., \& Woo, S. E. (2017). Exploratory data analysis as a foundation of inductive research. Human Resource Management Review, 27(2), 265-276.

25.Johnson, R. R., Chittenden, W. T., \& Jensen, G. R. (1999). Presidential politics, stocks, bonds, bills, and inflation. The Journal of Portfolio Management, 26(1), 27-31.

26.Loretan, M., \& Phillips, P. C. (1994). Testing the covariance stationarity of heavy-tailed time series: An overview of the theory with applications to several financial datasets. Journal of Empirical Finance, 1(2), 211-248. 
27.Niederhoffer, V., Gibbs, S., \& Bullock, J. (1970). Presidential elections and the stock market. Financial Analysts Journal, 111-113.

28.Qadir, U. (2016). Pakistan \& s automotive industry: a case of stalled development. Pakistan Institute of Development Economics.

29.Riley, W. B., \& Luksetich, W. A. (1980). The market prefers republicans: Myth or reality. Journal of Financial and Quantitative Analysis, 15(3), 541-560.

30.Santa-Clara, P., \& Valkanov, R. (2003). The presidential puzzle: Political cycles and the stock market. The Journal of Finance, 58(5), 1841-1872.

31.Shah, A. (1984). Crowding out, capital accumulation, the stock market, and money-financed fiscal policy. Journal of money, credit and banking, 16(4), 461-473.

32.Snowberg, E., Wolfers, J., \& Zitzewitz, E. (2007). Partisan impacts on the economy: evidence from prediction markets and close elections. The quarterly journal of economics, 122(2), 807-829.

33.Sy, O., \& Al Zaman, A. (2011). Resolving the presidential puzzle. Financial Management, 40(2), 331-355.

34.Thorbecke, W. (1997). On stock market returns and monetary policy. The Journal of Finance, 52(2), 635-654.

35.Wisniewski, T. P. (2016). Is there a link between politics and stock returns? A literature survey. International Review of Financial Analysis, 47, 15-23. 